\section{Report of two medicinal and aromatic gingers from Andaman and Nicobar Islands, India}

\section{Venkat Ramana ${ }^{1}$, Johny Kumar Tagore ${ }^{2}$ \& Avishek Bhattacharjee ${ }^{3}$}

\author{
1,2 Botanical Survey of India, Andaman and Nicobar Regional \\ Centre, Haddo, Port Blair, Andaman and Nicobar Islands \\ 744102, India \\ ${ }^{3}$ Central National Herbarium, Botanical Survey of India, A.J.C.B \\ Indian Botanic Garden, Howrah, West Bengal 711103, India \\ Email: 1 venkat.botany@gmail.com, 2jktagore@gmail.com, \\ ${ }^{3}$ aviorch@gmail.com (corresponding author)
}

The Andaman and Nicobar Islands are the largest archipelago situated $1200 \mathrm{~km}$ off the southeastern coast of India in the Bay of Bengal stretching from Myanmar in the north to Sumatra in the south. These islands, forming an arc, are situated between $06^{\circ} 45^{\prime}-$ $13^{\circ} 41^{\prime} \mathrm{N}$ and $92^{\circ} 12^{\prime}-93^{\circ} 57^{\prime} \mathrm{E}$ with a total geographical area of $8,249 \mathrm{~km}^{2}$. The islands have developed a luxuriant tropical lowland vegetation, owing to the tropical hot, humid, and wet conditions, facilitating the formation of luxuriant tropical evergreen forests, wetland forests, tidal swamp forests, mangroves and sandy beach vegetation. The phytodiversity of these

Date of publication (online): 26 May 2012

Date of publication (print): 26 May 2012

ISSN $0974-7907$ (online) | $0974-7893$ (print)

Editor: N.P. Balakrishnan

Manuscript details:

Ms \# 02983

Received 31 October 2011

Final received 06 March 2012

Finally accepted 27 April 2012

Citation: Ramana, M.V., J.K. Tagore \& A. Bhattacharjee (2012). Report of two medicinal and aromatic gingers from Andaman and Nicobar Islands, India. Journal of Threatened Taxa 4(5): 2582-2586.

Copyright: (c) M. Venkat Ramana, Johny Kumar Tagore \& Avishek Bhattacharjee 2012. Creative Commons Attribution 3.0 Unported License JoTT allows unrestricted use of this article in any medium for non-profit purposes, reproduction and distribution by providing adequate credit to the authors and the source of publication.

Acknowledgement: The authors (MVR \& JKT) are grateful to the Department of Biotechnology, Ministry of Science \& Technology, New Delhi, India, for the fellowship under the project entitled 'Mapping of Plant Resources of Andaman and Nicobar Islands'. They are also thankful to the Project Coordinator, Prof. K.N. Ganeshaiah, UAS, GKVK, Bangalore; Principal Investigator, Dr. M. Sanjappa, former Director, Botanical Survey of India and Dr. P. Singh, Director, Botanical Survey of India, Kolkata for facilities.

OPEN ACCESS | FREE DOWNLOAD

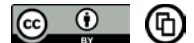

islands is unique and is one of the richest in the country in terms of endemics with a remarkable

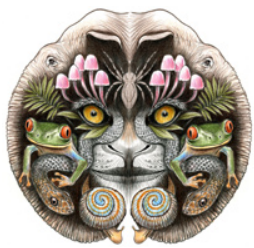
degree of genetic variations.

While working on 'Quantitative Assessment and Mapping of Plant Resources of the Andaman and Nicobar Islands', some specimens belonging to the family Zingiberaceae were collected from Mayabundar forest division of North Andaman Islands. On critical study and detailed examination of these specimens, they were identified as Alpinia conchigera Griff. and Etlingera linguiformis (Roxb.) R.M. Sm. Consultation of literature (Srivastava 1998; Sinha 1999; Pandey \& Diwakar 2008; Gingers of India 2011) reveals that these two species have not been reported so far from the Andaman and Nicobar Islands. Therefore, the present finding constitutes a new distributional record of $A$. conchigera and E. linguiformis for the Andaman and Nicobar Islands.

Alpinia conchigera Griff. in Not. Pl. Asiat. 3: 424. 1851; Baker in Hook.f., Fl. Brit. India 6: 253. 1893. (Image 1)

Rhizomatous herbs, 1-1.5 m tall; rhizomes aromatic; basal portion of aerial stems pinkish. Leaves simple, distichous; lamina oblong to lanceolate, 15-20 $\times 1-3 \mathrm{~cm}$, obtuse at base, acute to acuminate at apex, dark green above, pale beneath, glabrous on upper and lower surfaces; ligule entire, ca. $5 \mathrm{~mm}$ long, glabrous; petiole 5-10 mm long. Panicles 1- or 2-branched, 15$30 \mathrm{~cm}$ long; peduncle pubescent with sterile bracts; bracts ca. 5mm long; bracteoles funnel-shaped, 3-4 $\mathrm{mm}$ long, obliquely truncate at apex; pedicels ca. $5 \mathrm{~mm}$ long. Calyx cupular, 3-4 mm long, 3-cleft at apex, pale green. Corolla tube as long as calyx; lobes 5-8 mm long, central one rounded at apex, pale green. Lateral staminodes quadrate, ca. $1.5 \mathrm{~mm}$ long, red. Labellum orbicular, concave, ca. $5 \times 5 \mathrm{~mm}$, pale yellow with pinkish and reddish streaks, base with a purple callosity covering corolla throat. Filaments slender, ca. $5 \mathrm{~mm}$ long, pinkish to yellow. Anther ca. $2 \mathrm{~mm}$ long. Ovary pyriform, glabrous. Capsule globose, ca. $10 \mathrm{~mm}$ in dia., with persistent calyx, bluish-black when ripe; seeds 3-5, strongly aromatic.

Specimens examined: 28.viii.2011, 12049'40.4'N \& 92054'58.9'E, 12m, Karmatang 10, Mayabunder, North Andaman, Andaman \& Nicobar Islands, India, 

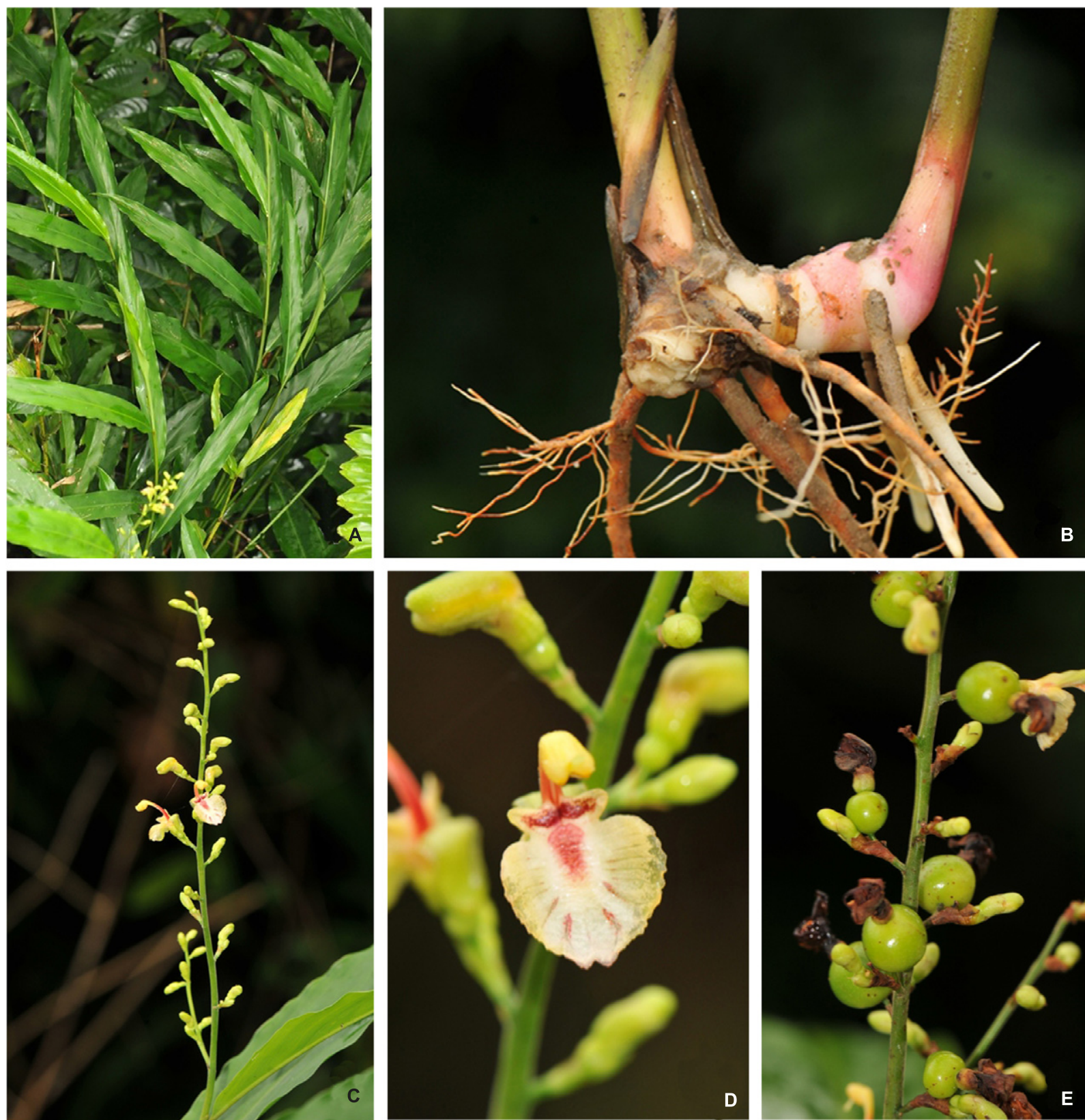

Image 1. Alpinia conchigera Griff.

A - Habit; B - rhizome; C - Inflorescence; D - flower; E - capsules.

M.V. Ramana \& J.K. Tagore 0424 (PBL, CAL) (Image 2).

\section{Flowering \& Fruiting: August-October.}

Habitat: The species was found growing in damp marshy localities along forest edges and water canals in evergreen forests; not common.

Distribution: Bangladesh, Cambodia, India (northeastern India and now from Andaman and Nicobar Islands), Indonesia, Laos, Malaysia, Myanmar, Thailand and Vietnam.
Local use: Young leaves and shoots are used as leafy vegetables; rhizomes are used as medicine to cure jaundice by the Karen people (of Burmese origin) in the Mayabundar forest range, North Andaman Islands.

Active principles: The slender rhizomes of A. conchigera are a stimulating, diaphoretic, and regulatory in uterine haemorrhage and used to treat bronchitis, jaundice, headache, vertigo, metritis (inflammation of the endometrium of the 


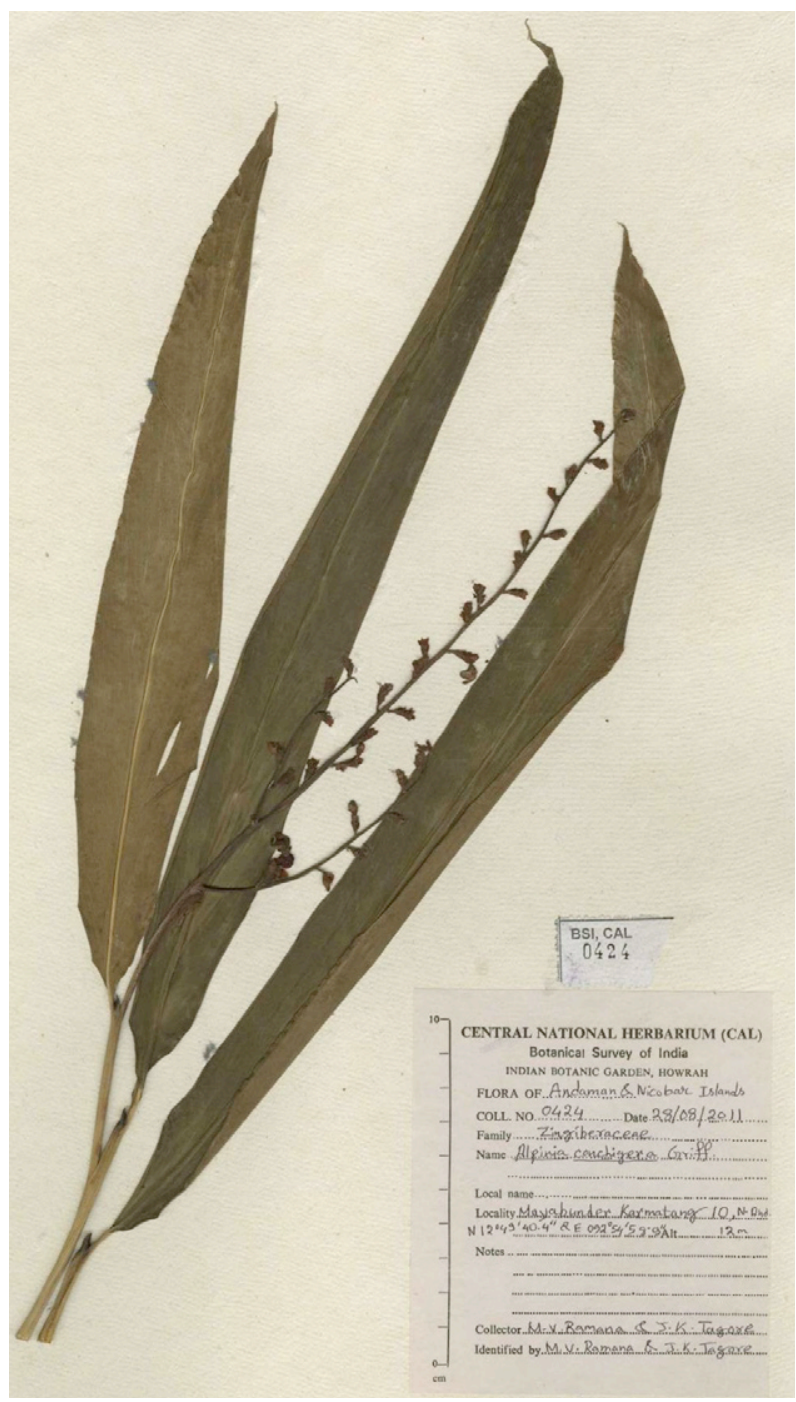

Image 2. Herbarium specimen of Alpinia conchigera Griff.

uterus). It is also used externally for treatment of rheumatism and arthritis (Holttum 1950). It showed antimicrobial activities (Wasuwat et al. 1986), and anti-inflamatory activities (Lee et al. 2006). The major components in the essential oil extracted from the rhizomes, according to Sirat et al. (1995), are $\beta$-sesquiphellandrene (20.5\%), $\beta$-bisabolene (12.1\%) and 1,8-cineole (11.6\%). Anita et al. (2000) reported that the essential oil contains bi-cyclo 4,1,11-trimethyl8-methlene-undec-4-ene and $\beta$-bisabolene and Wong et al. (2005) reported the presence of terpenoids with $\beta$-bisabolene $(28.9 \%), 1,8$-cineole $(15.3 \%)$ and $\beta$-caryophyllene (10.0\%). The rhizomes are also found to be rich in $\beta$-sitosterol, stigmasterol, cardamomin, chalconaringenin 2-O-methyl ether, alpinetin and naringenin 5-O-methyle ether (Le et al. 2007).
Etlingera linguiformis (Roxb.) R.M. Sm. in Notes Roy. Bot. Gard. Edinburgh 43(2): 246. 1986. Alpinia linguiformis Roxb., Fl. Ind. 1: 73. 1820.

(Image 3)

Rhizomatous perennial herbs, up to $2 \mathrm{~m}$ tall; rhizomes stoloniferous, strongly aromatic; aerial stems robust, yellowish, shining. Leaves simple, distichous, lamina oblong to lanceolate, $20-35 \times 4-6$ $\mathrm{cm}$, glabrous, shining above, rounded to acute at base, acute to acuminate at apex; ligules entire, ca. $5 \mathrm{~mm}$ long, glabrous, ciliate at apex; petioles ca. $2 \mathrm{~cm}$ long. Spikes few-flowered, arising from rhizomes, oblong, narrowed at both ends, $6-8 \mathrm{~cm}$ long, red, flowers arranged in 3-4 concentric circles; peduncles short, 1.5 to $2 \mathrm{~cm}$ long, raised above the ground level with sterile bracts; bracts orbicular, concave, ca. $2 \times 2 \mathrm{~cm}$, pinkish green; bracteoles oblong, ca. $3.5 \times 1.5 \mathrm{~cm}$, acute at apex. Calyx tubular, ca. $3 \mathrm{~cm}$ long, split on one side, 2-toothed at apex. Corolla tube as long as calyx, 3-lobed, lobes shorter than tube. Lateral staminodes absent. Lip oblong, tongue-shaped, ca. $5 \mathrm{~cm}$ long, bright yellow with reddish tinge, deflexed, folded below the middle, 2-lobed or entire at apex. Stamens as long as style; anthers ca. $8 \mathrm{~mm}$ long. Ovary oblong, ca. $4 \mathrm{~mm}$ long, silky hairy, 3-loculed; ovules numerous per locule; style ca. $6 \mathrm{~cm}$ long; stigma capitate.

Specimens examined: 27.viii.2011, $12^{\circ} 49^{\prime} 04.9^{\prime \prime} \mathrm{N}$ \& 92 $2^{\circ} 55^{\prime} 48.4$ 'E, 30m, Karmatang 11, Mayabunder forest division, North Andaman, Andaman and Nicobar Islands, India, M.V. Ramana \& J.K. Tagore 0402 (PBL, CAL) (Image 4).

Flowering \& Fruiting: August-November.

Habitat: The species was found growing in damp marshy places in forest edges and along water canals in evergreen forests; planted near houses for its aromatic stolons and rhizomes that are used as local medicine; not common.

Distribution: India (northeastern India and now from Andaman and Nicobar Islands), Myanmar

Local use: The stoloniferous rhizomes give an aroma similar to that of Foeniculum vulgare (Apiaceae). The rhizomes are crushed and the extract, mixed with water, is consumed to treat fever chiefly by the Karen people of the Mayabundar forest range, North Andaman Islands.

Active principles: The stoloniferous rhizomes of E. linguiformis are strongly aromatic. Fresh rhizomes contain about $0.4 \%$ essential oil with a fennel like smell, 

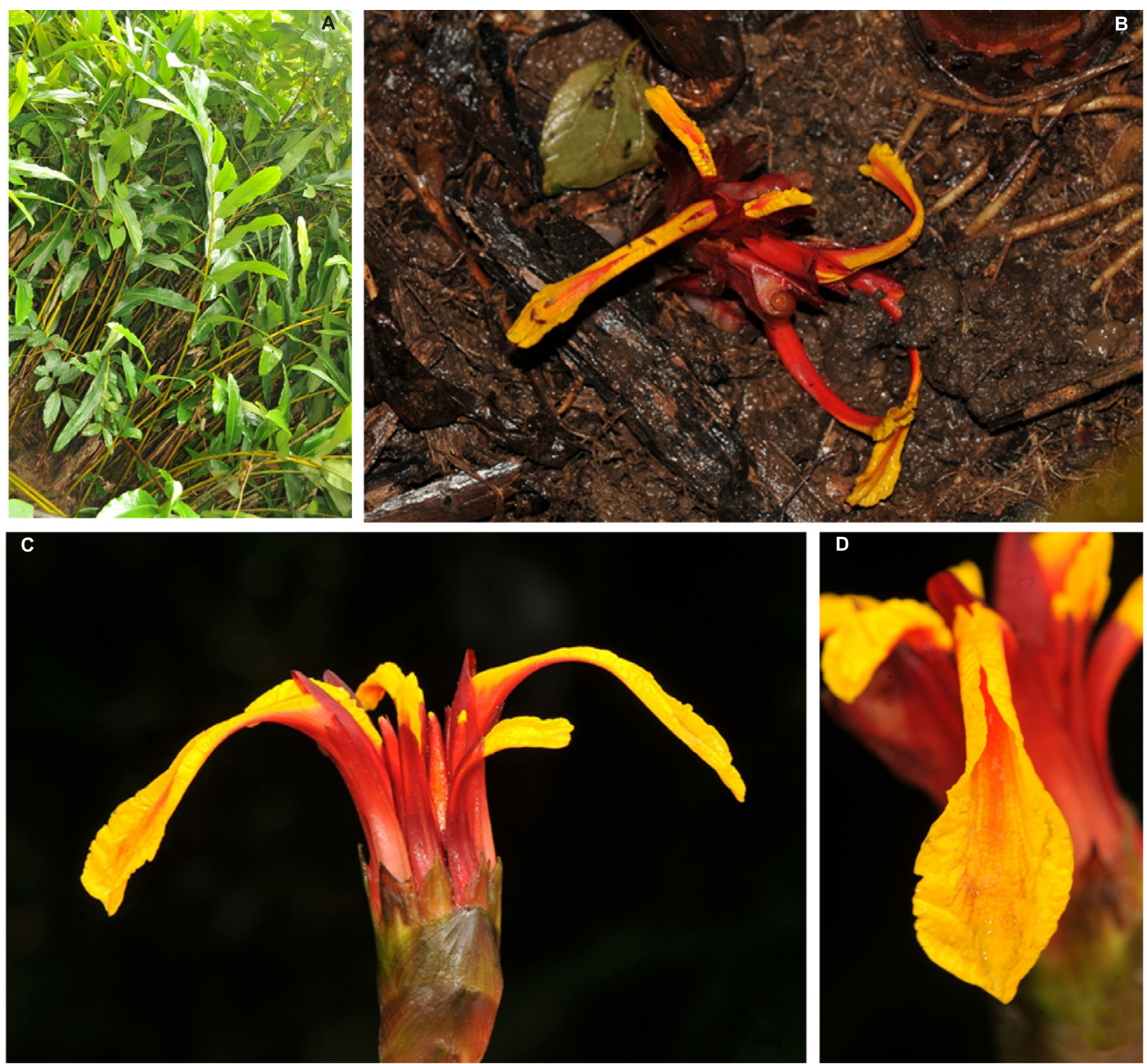

Image 3. Etlingera linguiformis Roxb. - R.M. Sm. A - Habit; B - Inflorescence; C - Spike; D - Lip.

composed of about 19 components, a few of them are methyl chevicol (49.93\%), methyl eugenol (32.3\%), $\beta$-pinene, asarone, eucalyptol and $\alpha$-pinene. The fresh leaves contain $0.15 \%$ essential oils, composed of about 39 components; a few are eucalyptol (39.69\%), $\beta$-pinene (13.34\%), $\alpha$-pinene $(7.80 \%), \quad$ linalool (7.39\%), $\beta$-elemene, $\alpha$-selinene, $\beta$-terpinyl acetate, $\alpha$-phellandrene and juniper camphor (MPB 2011).

\section{REFERENCES}

Anita, H., A.M. Mustafa \& I. Halijah (2000). Studies on essential oils of Alpinia conchigera Griff. from Malaysia. Malaysian Journal of Science 9(1): 1-5.

Gingers of India (2011). <http://www.gingersofindia.com>. Online version dated 23 September 2011.

Holttum, R.E. (1950). The Zingiberaceae of the Malay Peninsula. Gardens' Bulletin Singapore 13: 147.

Le, H.T., M.G. Phan \& T.S. Phan (2007). Further study on chemical constituents and biological activities of Alpinia conchigera Griff. (Zingiberaceae). Tap Chi Hoa Hoc 45(2): 260-264.

Lee, J., S.J. Haeng, M.G. Phan, J. Xuejun, S. Lee, T.S. Phan, D. Lee, Y. Hong, K. Lee \& J.L. Jung (2006). Blockade of nuclear factor- $\mathrm{\kappa B}$ signalling pathway and anti-inflammatory activity of cardamomin, a chalcone analog from Alpinia conchigera. Journal of Pharmacology and Experimental 


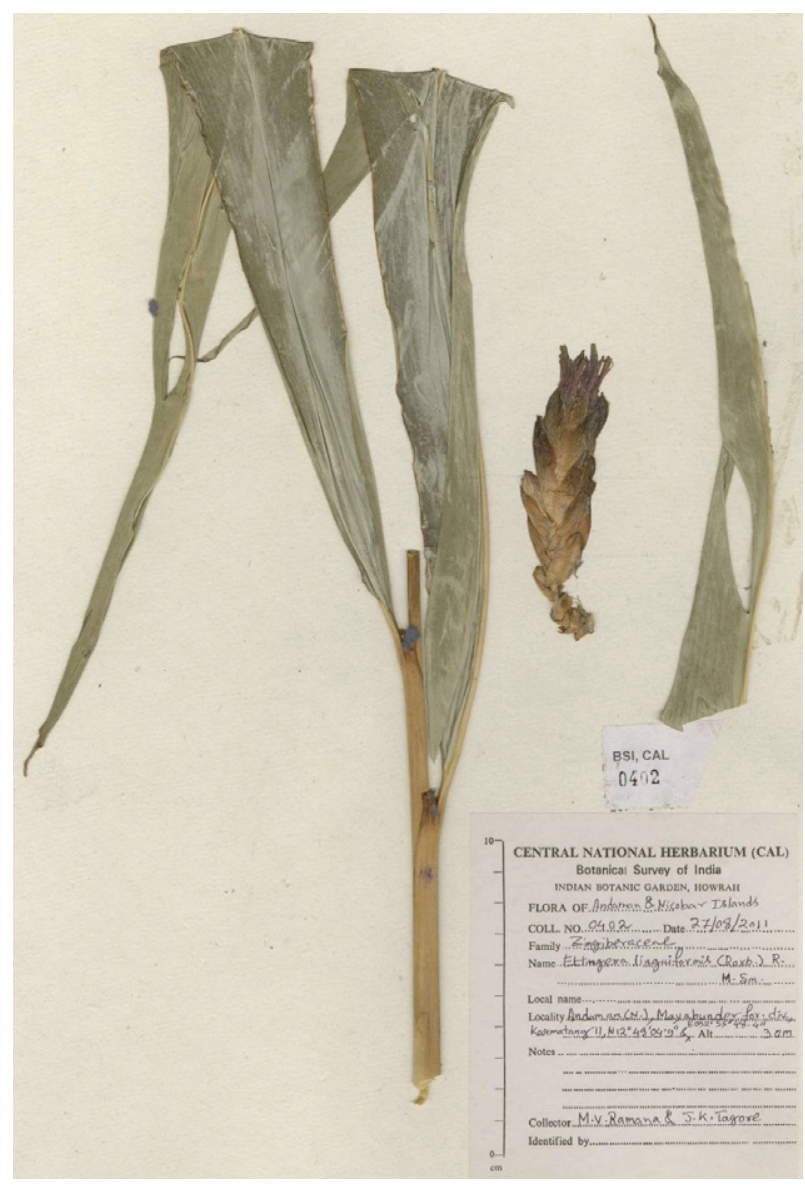

Image 4. Herbarium specimen of Etlingera linguiformis (Roxb.) R.M. Sm.
Therapeutics 316(1): 271-278.

Medicinal Plants of Bangladesh [MPB] (2011). Etlingera linguiformis. $\quad<$ http://www.mpbd.info/plants/etlingeralinguiformis.php $>$. Online version dated 23 September 2011.

Pandey, R.P. \& P.G. Diwakar (2008). An Integrated Checklist of Andaman and Nicobar Islands, India. Journal of Economic and Taxonomic Botany 32(2): 403-500.

Sinha, B.K. 1999. Zingiberaceae, pp. 447-449. In: Hajra, P.K. \& P.S.N. Rao (eds.). Flora of Great Nicobar Island. Botanical Survey of India, Calcutta.

Srivastava, S.K (1998). Zingiberaceae in Andaman \& Nicobar Islands, India. Indian Journal of Forestry, Additional Series 10: $1-33$.

Wasuwat, S., P. Wannissorn, W. Chamchaang, T. Suntorntanasat, P. Soontornsaratune \& A. Chotippong (1986). Pharmaceuticals from medicinal plants: Pharmacological study on the antibacterial and antifungal activity of active principles from Alpinia conchigera Griff. Thailand Institute of Scientific and Technological Research, Bangkok, 19p.

Wong, K.C., B.C. Lee, N.F. Lam \& P. Ibrahim (2005). Essential oils of the rhizomes of Alpinia conchigera Griff. and Alpinia latilabris Ridl. Flavour and Fragrance Journal 20(4): 431-433. 